\title{
Asylum appeals: is there a better way?
}

\author{
by Judge David Pearl
}



Judge David Pearl

In this article based on a public lecture delivered at the Institute of Advanced Legal Studies on 6 November 1999, Judge Pearl argues the case for a review of current procedures for dealing with asylum appeals and for consideration of a complete overhaul of administrative justice systems.

A sylum status determination has had a very difficult press in recent years, in part because of the considerable media interest in the subject. Asylum stories have been pouring out of the developed world's newspapers. By way of an example, the Belgian press has not been far behind some of the British media in highlighting the problems arising out of those seeking asylum. Thus on 11 October 1999 it was reported that:

. just three months old, Claudia Joskova badly needs a hernia operation. It is only one of her smaller problems in life. For half her existence Claudia has been on the run, ending up in a dark, decrepit classroom that her parents temporarily call home, some 1,500 miles from her birthplace in the Kosic area of Slovakia. Like hundreds of Kosice Gypsies, the Joskovas are seeking asylum in Belgium at a time when countries across the European Union are trying to halt a rising tide of would-be immigrants.'

Political parties across Europe, in Switzerland and Austria in particular, have benefited from the concerns of those who wish to 'halt a rising tide of would-be immigrants'. In Ghent, as in Dover, city leaders are reported to have said that there has to be a stop to this, because the tolerance threshold has vanished. Media coverage in the UK of the Stansted Airport hijack incident illustrates in an all too stark form the virtual disintegration of a tolerant level.

In the European context, a high-level working group on Asylum and Migration has been engaged in conducting action plans both for selected countries of origin and for transit across states of asylum seekers. The European Council, at its meeting in Tampere, Finland, on 15 and 16 October 1999, adopted the proposals of the Working Group and progressed towards a common EU policy. The Presidency Conclusions state:

'The European Council reaffirms the importance the Union and Member States attach to absolute respect of the right to seek asylum. It has agreed to work towards establishing a common European asylum system, based on the full and inclusive application of the Geneva Convention, thus ensuring that nobody is sent back to persecution, i.e. maintaining the principle of non-refoulement.
Amongst the general propositions within this statement of policy is an acceptance of common standards for a fair and efficient asylum procedure and the approximation of rules on the recognition and content of refugee status. Community rules should lead to a common asylum procedure and a uniform status for those who are granted asylum valid throughout the Union. This is however a long way off at the present time.

International law norms are essentially underdeveloped and provide little in the way of guidance in developing a model for refugee-status determination. Guy Goodwin-Gill, in The Refugee in International Law, refers to the following as minimum standards:

- knowledge of the case against one;

- an opportunity to submit evidence to rebut that case;

- reasoned negative decisions;

- the right to appeal against any adverse decision before an impartial tribunal independent of the initial decision-making body.

The Geneva Convention itself is silent when considering these procedural safeguards, and the UNHCR Executive Committee has said very little to develop any further guidance. Their Handbook, at para. 46, is equally undemanding, referring simply to:

a formal reconsideration of the decision, either to the same or to a different authority, whether administrative or judicial, according to the prevailing system.'

The EU Intergovernmental Resolution on Minimum Guarantees on Asylum Procedures (5585/95) states:

'In the case of a negative decision, provision shall be made for an appeal to a court or a review authority which gives an independent ruling on individual cases under conditions laid down.

There is therefore both in international law and practice and in European law an acceptance that there must be some provision for a merits appeal separate from the executive arm of 
government. It is my view that the merits appeal should be a last resort, to provide a safeguard against a wrong conclusion drawn by the initial decision maker. Unfortunately, this has not been the experience here in the UK. I believe strongly that resources should be front loaded, so that there is high quality initial decision making which would ensure appeal processes would only occasionally be required. A similar point has been made by every report and research project that has looked at this question over recent years. Under-resourcing at the early level simply leads to a paper pushing excrcise, whereby cases are shifted from the Home Office to the Immigration Appellate Authorities and where all too often the Adjudicator (the first level of appeal at the Immigration Appellate Authorities) is in effect the first person to provide a scrious analysis of the factual and legal situation presented by the applicant.

By way of an illustration, I can refer to the decision of Horrath v Secretary of State 1999 Imm AR 21, upheld by the Court of Appeal on 2 December 1999, where the tribunal commented critically on the standard of the initial interview and the refusal letter sent to the applicant by the Secretary of State. It even went as far as to suggest that the refusal letter seemed to bear no relation to the story of what had happened to this applicant and his family as told to the interviewing officer and as repeated to the adjudicator:

The quality of decision making at the first and executive level is often justified by government ministers and their spokespersons by pointing to the low level of successful appeals, which in their view underlines the quality of the initial decision making. This approach is in my view misconceived. The Commission for Racial Equality said in 1985:

'It would be a mistake to suppose that if an administrative system is seriously flawed, a system of appeals against it will correct those defects. It will not.

It is both a false economy and a flawed legal system which places emphasis solely on appeal rights.

\section{LACK OF INTERNATIONAL NORMS}

We need a judicial framework to ensure that people who allege that they will be persecuted if returned to their country of origin for one of the specified Geneva Convention reasons have their cases fairly and impartially considered. Persecution itself is not an easy concept to handle. Neither are some of the Convention's reasons, especially the definition of 'social group'. And there is no satisfactory international law definition of any of these concepts. To criticise the adjudicators and the tribunal for lack of consistency of approach is easy; but it stems from a failure to have common international law norms, leaving us all free to interpret the Convention as we will.

\section{PRESENT SYSTEM AND ITS DEFECTS}

The structure for asylum appeals in the UK has in effect been planted in the same soil as the well-watered system of immigration appeals. The system for immigration appeals was established in the UK in 1970 to deal with appeals from adverse decisions of Home Office officials concerning immigration into the UK either on a short term basis or for indefinite leave, and appeals from entry clearance officers refusing visas. The original suggestion was that there be a tribunal composed of a legally qualified chairman and two lay members hearing appeals from 'subordinate judicial officers' (called adjudicators) at ports. These 'judicial officers' would deal with an appeal immediately after the refusal by an immigration officer and these hearings would be followed by an immediate oral determination.

In practice that never happened, and what has developed is a sophisticated body of procedural rules and case law. This judicialisation, especially in the asylum context, has been much criticised. In desperation, it has been suggested that one tier should be removed, that the lay element of the tribunal should be removed, that judicial review of the refusal by a tribunal chairman of leave to appeal to the tribunal should be abolished, that more cases should be subjected to an expedited procedure, that draconian case management and time consequences should be imposed. The legislation in 1993, 1996 and now 1999, has all been directed at accelerating the procedures.

I personally believe that the emphasis on the procedural aspects of the issue hides the fundamental issue. We need a judicial framework to ensure that people who allege that they will be persecuted if returned to their country of origin for one of the specified Geneva Convention reasons have their cases fairly and impartially considered. Persecution itself is not an easy concept to handle. Neither are some of the Convention reasons, especially the definition of 'social group'. And there is no satisfactory international law definition of any of these concepts. To criticise the adjudicators and the tribunal for lack of consistency of approach is easy; but it stems from a failure to have common international law norms, leaving us all free to interpret the Convention as we will.

Judicial review is a blunt instrument, emphasising procedural defects, for example, in cases where a chairman of a tribunal has refused leave to appeal to itself, or where an adjudicator has dismissed an accelerated 'certified' appeal.

The current structure of appeals has not made it easy to provide answers to the complex questions of substantive law; for example to set out a consistent framework for issues such as internal flight, persecution in the context of a civil war (that is, being caught in the crossfire), and when discrimination becomes persecution.

\section{A PROPOSAL}

The time has come, in my view, to grasp the nettle of judicial review. Much of my time as President was spent either agreeing to Treasury Solicitor's proposals to quash a chairman's refusal of leave to appeal to the tribunal or trying, usually unsuccessfully, to persuade him to fight a judicial review challenge. I was never certain of the constitutional position of these deliberations, not least in that although technically the tribunal's decision is the one which is being challenged, the tribunal is not itself represented, and the Treasury Solicitor's client is the Secretary of State, who is a party to the proceedings before the Immigration Appellate Authorities. The volume of appeals is compounded by tight time limits, and failure by the Immigration Appeal Tribunal to consider the application for leave to appeal to itself within the specified time limits results in leave to appeal having been deemed to have been granted. Rigid time limits for filing grounds for appeal from the adjudicators to the tribunal, and draconian results for the tribunal if they fail to 
deal with the matter within further tight time scales, are counter-productive. Representatives have little choice but to file protective appeals (even the Secretary of State does this); and chairmen have little time to deal with the appeal except by way of a formulaic procedure.

I would suggest that the opportunity should be taken to consider a complete overhaul of administrative justice, for some of the difficulties outlined here in relation to asylum status determination apply equally in other tribunal structures. I believe that the larger tribunal systems, especially Immigration and Asylum, Mental Health, Employment, and the Social Security and Tax Tribunals, should be loosely co-ordinated into an administrative court, with a second tier being granted a Court of Record status with High Court Judges serving as chairmen. There should then be an appeal from these courts on a point of law to the Court of Appeal. Judicial review would be available, of course, in the event of any procedural error within the system, but I suspect that the Crown Office would not be engaged to any great extent. The Australian model of a multijurisdictional Administrative Appeal Tribunal bears close scrutiny. Judicial review has played its part in developing the system of administrative law in this country, but now, with the Human Rights Act 1998 nearing implementation, we should be concentrating on substantive rights rather than on procedural defects. This may be a dream, but I do think it worthy of serious debate. (c)

Judge David Pearl

Director of Studies, Judicial Studies Board

Judge Pearl has been both President of the Immigration Appeal Tribunal and Chief Adjudicator, Immigration Appeals.
Developed by lawyers for lawyers

COMING SOON... Personalised online and e-mail alerting
Legal Information as it Happens

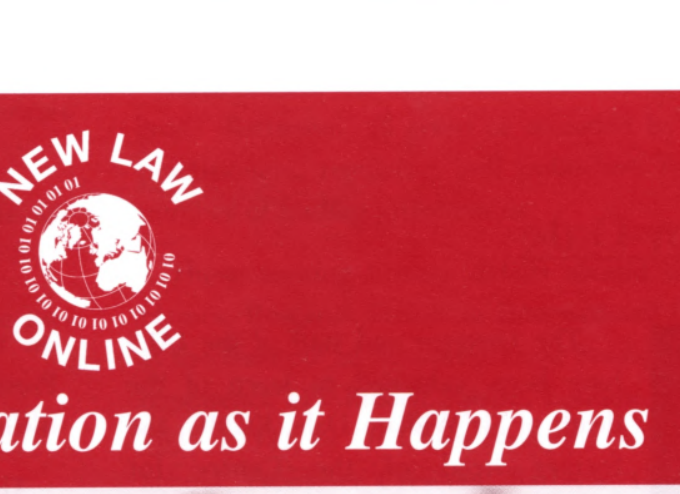

